Archives of Agriculture and Environmental Science

\title{
Effects of mulching on growth and yield components of selected varieties of wheat (Triticum aestivum L.) under field condition
}

\author{
S. Akter ${ }^{1}$, U.K. Sarker ${ }^{1}$, A.K. Hasan ${ }^{1}$, M.R. Uddin ${ }^{1}$, M.M.I. Hoque ${ }^{2}$ and C.K. Mahapatra ${ }^{3}$ \\ ${ }^{1}$ Department of Agronomy, Bangladesh Agricultural University, Mymensingh-2202, BANGLADESH \\ ${ }^{2} \mathrm{ACI}$ Limited, Dhaka, BANGLADESH ${ }^{3}$ Upazila Agriculture Officer, Kendua, Netrakona, BANGLADESH \\ *Corresponding author's E-mail: romijagron@bau.edu.bd
}

\section{ARTICLE HISTORY}

Received: 20 January 2018

Revised received: 11 February 2018

Accepted: 20 February 2018

Keywords

Harvest index

Leaf area index

Mulching

Total dry matter

Wheat varieties

Yield components

\begin{abstract}
Wheat is facing increased high temperature during its grain filling period in Bangladesh which reduces yield drastically. Mulching may help to mitigate this problem. Therefore, a field experiment was carried out at the Agronomy Field Laboratory, Bangladesh Agricultural University, Mymensingh during the period from November 2015 to March 2016 to find out growth and yield performance of wheat as influenced by mulching. The experiment comprised of two factors viz., variety and mulching. The variety comprised of BARI Gom-26, BARI Gom-27 and BARI Gom-28. Mulching comprised of four different levels of treatments viz.no mulch + no irrigation (control), water hyacinth mulch + no irrigation, rice straw mulch + no irrigation and two irrigations at CRI and flowering stage. The experiment was laid out in a randomized complete block design with three replications. BARI Gom-28 showed the highest values in growth parameters (plant height, number of total tillers hill ${ }^{-1}$, LAI, chlorophyll content and total dry matter) at 30, 45 and 60 DAS. On the other hand, when mulching was compared, rice straw mulch gave higher yield compared to other treatments at 30, 45 and 60 DAS. The interaction effect of variety and mulching showed significant in relation to yield and yield components except plant height, spike length, 1000- grain weight and harvest index (\%). The tallest plant $(93.20 \mathrm{~cm})$ was obtained from the interaction of BARI Gom-28 and rice straw mulch. The highest number of total tillers hill ${ }^{-1}(4.80)$, number of effective tillers hill ${ }^{-1}$ (4.57), spike length (10.23), number of spikelets spike ${ }^{-1}$ (21.15), 1000-grain weight (48.54 g), grain yield ( $5.20 \mathrm{t} \mathrm{ha}$ $\left.{ }^{1}\right)$, straw yield $\left(7.27 \mathrm{t} \mathrm{ha}^{-1}\right)$, and harvest index (41.71\%) were obtained from the interaction of BARI Gom-28 and rice straw mulch. The lowest grain yield was obtained from BARI Gom-26 and control (no mulch + no irrigation). It may be concluded from the results of the study that, BARI Gom-28 with rice straw mulching treatment can be used for successful cultivation of wheat.
\end{abstract}

(C)2018 Agriculture and Environmental Science Academy

Citation of this article: Akter, S., Sarker, U.K., Hasan, A.K., Uddin, M.R., Hoque M.M.I. and Mahapatra, C.K. (2018). Effects of mulching on growth and yield components of selected varieties of wheat (Triticum aestivum L.) under field condition. Archives of Agriculture and Environmental Science, 3(1): 25-35 DOI: 10.26832/24566632.2018.030103

\section{INTRODUCTION}

Wheat (Triticum aestivum L.) is the second most important grain crop after rice in Bangladesh. It is used as principal food in most of the area of the world.Wheat belongs to the Grass familylt is grown on an around 220.4 million hectares land area. In 2016, wheat production around the world was 749 million tonnes which makes it the second most-produced cereal after maize (FAO, 2016). In Bangladesh the total area under wheat cultivation was 4,36, 814 hectares and average production was 3.086 metric tons per hectare (BBS, 2015). Wheat provides $21 \%$ of the food calories and $20 \%$ of the protein to more than 4.5 billion people in 94 developing countries (Braun et al., 2010). Wheat yields are significantly limited by the availability of water and nutrients, especially in arid and semi-arid regions. In regions with sufficient water and nutrient input, the water and nutrient use efficiencies of wheat are often low due to suboptimal management which leads to large losses in grain yield of wheat. Because of increased moisture scarcity throughout the growing season of wheat, it adversely affects the plant growth and development.

Surface-applied mulches provide several benefits to crop production through improving soil water, heat energy and nutrient status in soil, preventing soil and water loss, soil salinity from flowing back to surface, and controlling weeds. Mulching of 
wheat increases grain yield in comparison with unmulched wheat due to soil and water conservation, improved soil physical and chemical properties, and enhanced soil biological activity. Mulching increased soil moisture, which in turn improve winter wheat grain yield and water use efficiency (Chen et al., 2015). Mulching could improve soil water retention (Stagnari et al., 2014). This effect reduces soil water evaporation losses and increases plant transpiration rates. When irrigation is limited, mulching increases wheat yield, water use efficiency, and soil organic carbon fixation (Hari et al., 2013). Straw mulching significantly increased winter wheat grain yield (Marbet et al., 2012). In the same cropping system, conservation tillage and straw mulching significantly boosted yields, improved the use efficiency of limited water resources in arid areas, and lowered carbon emissions from farming.

In Bangladesh, the total cultivable land has been decreasing day by day due to increasing population. Urbanization, industrialization and construction of various institutions are increasing rapidly due to over population. That's why agricultural land for crop production is decreasing. On the other hand, farmers have the tendency to cultivate boro rice in November-April of wheat growing period. In this situation wheat cultivation can play an important role for maintaining the nutritional demand of these over population. There is an opportunity to increases production of wheat per unit area through adoption of improved agronomic practices including high yielding variety and different types of mulching. The present study was, therefore, undertaken to observe the performance of Bangladesh Agricultural Research Institute (BARI) released wheat varieties, to evaluate the effect of mulching on the yield of wheat and to find out the interaction effect of variety and mulching on the yield of wheat.

\section{MATERIALS AND METHODS}

The experiment was conducted at the Agronomy Field Laboratory, Bangladesh Agricultural University, Mymensingh during the period from November 2015 to March 2016. The experimental field was located at $24^{\circ} 75^{\prime} \mathrm{N}$ latitude and $90^{\circ} 50^{\prime} \mathrm{E}$ longitude at an elevation of $18 \mathrm{~m}$ above the sea level belonging to non -calcareous dark grey floodplain soil under Old Brahmaputra Floodplain Agro-ecological zone-"AEZ 9". The experimental plot was a medium high land with silty clay loam soil having $\mathrm{pH} 5.80$. The experimental site belongs to the subtropical area characterized by heavy rainfall during kharif season (April to September) and scanty in the rabi season (October to March) associated with moderately low temperature and plenty of sunshine. The experimental treatments consisted of two factors viz., varie-


and mulching, $M_{1}-$ no mulch + no irrigation (control), $M_{2}-$ mulching with water hyacinth + no irrigation, $M_{3}$-mulching with rice straw + no irrigation, $\mathrm{M}_{4^{-}}$two irrigations at $\mathrm{CRI}$ and flowering stage. The experiment was laid out in a randomized complete block design with three replications. The unit plot size was $4 \mathrm{~m} \times 2.5 \mathrm{~m}$. Plant to plant and row to row distance were $5 \mathrm{~cm}$ and $20 \mathrm{~cm}$, respectively.

The experimental field was prepared with power tiller followed by laddering. All the weeds and stubble were removed from the field and made ready for sowing. In case of irrigated plot, the land was uniformly fertilized with $180 \mathrm{~kg}$ urea, $180 \mathrm{~kg}$ triple super phosphate (TSP), $50 \mathrm{~kg}$ muriate of potash (MoP) and 120 $\mathrm{kg}$ gypsum ha ${ }^{-1}$. On the other hand $180 \mathrm{~kg}$ urea, $180 \mathrm{~kg}$ triple super phosphate (TSP), $40 \mathrm{~kg}$ muriate of potash (MoP) and $90 \mathrm{~kg}$ gypsum was applied in case of without irrigated plot. Total amount of TSP, MoP and gypsum was applied in each plot at the time of final land preparation and the fertilizers were mixed thoroughly with soil by spading. Urea was top dressed in two equal splits. The seeds were sown in $25 \mathrm{~cm}$ apart rows by hand on $16^{\text {th }}$ of November, 2015. Germination of wheat was started on $20^{\text {th }}$ of November, 2015. Mulching such as water hyacinth and rice straw were applied on $26^{\text {th }}$ November, 2015. First irrigation was applied at crown root initiation stage (CRI) on 6 December, 2015 and second irrigation was applied at flowering stage on 15 January, 2016. The experimental crop was harvested on 13 March, 2016 at maturity. Harvesting was done plot wise and threshing, cleaning and drying was done accordingly. Data on growth parameters, yield and yield components were recorded from the sample plots. The recorded data were statistically analyzed using the "Analysis of Variance" technique and the differences among treatment means were adjudged by Duncan's New Multiple Range Test and Least Significant Difference Test whenever necessary (Gomez and Gomez, 1984).

\section{RESULTS AND DISCUSSION}

\section{Growth parameters}

Plant height $(\mathrm{cm})$ : The plant height was significantly affected by wheat variety and mulching at $1 \%$ level of probability at 30,45 and 60 days after sowing (DAS). BARI Gom-28 produced the longest plant of $36.83,63.06$ and $84.16 \mathrm{~cm}$ at 30,45 and 60 days after sowing, respectively. On the contrary, BARI Gom-26 gave the shortest plant of $29.07,43.22$ and $72.63 \mathrm{~cm}$ at 30,45 and 60 DAS, respectively (Figure 1). This is may be due to the genetic inheritance of the variety. The longest plant of 34.92, 53.96 and $83.62 \mathrm{~cm}$ was observed in rice straw mulch at 30,45 and 60 DAS, respectively. On the contrary, the shortest plant of 31.04 , 52.03 and $71.65 \mathrm{~cm}$ was obtained from control at 30, 45 and 60 DAS, respectively (Figure 2). Straw mulch conserved more soil moisture than control. The result is partially similar to that reported by Misra (1996), who found that soil mulching increased the availability of conserved moisture in the soil profile and significantly enhanced plant water use efficiency and plant height. There was significant difference in the plant height due to interaction of variety and mulching except 30 DAS (Table 1). However, numerically the tallest plant $(91.07 \mathrm{~cm})$ was found in $V_{3} \times M_{3}$ and shortest plant $(69.20 \mathrm{~cm})$ was found in $V_{1} \times M_{1}$ at 60 DAS.

Number of total tillers hill ${ }^{-1}$ : The number of total tillers hill ${ }^{-1}$ was significantly affected by wheat variety and mulching at $1 \%$ level 
of probability at 30, 45 and 60 DAS. BARI Gom-28 produced significantly the highest number of total tillers hill ${ }^{-1}$ of $3.69,5.30$ and 6.02 at 30, 45 and 60 days after sowing, respectively. On the contrary, BARI-Gom 26 gave the lowest number of total tillers hill ${ }^{-1}$ of $3.385,4.382$ and 4.702 at 30, 45 and 60 DAS, respectively (Figure 3 ). The highest number of total tillers hill ${ }^{-1}$ of 3.5, 4.98 and 5.59 was observed in rice straw mulch at 30,45 and 60 DAS, respectively. On the contrary, the lowest number of total tillers hill ${ }^{-1}$ of $3.51,4.51$ and 4.85 was obtained from control at 30, 45 and 60 DAS, respectively (Figure 4). Mulching might have reduced the fluctuation of soil temperature and increased the soil moisture and resulted more rapid crop growth and produced more number of tillers. The result was partially similar to the findings of Misra (1996) who stated that soil mulching significantly enhanced the number of tillers plant ${ }^{-1}$. There was significant difference in the total number of tillers hill ${ }^{-1}$ due to interaction of variety and mulching at 30, 45 \& 60 DAS. BARI Gom-28 produced significantly the highest number of total tillers hill $^{-1}$ of 5.73 and 6.75 in rice straw mulch at 45 and 60 days after sowing respectively. On the contrary, BARI Gom26 gave the lowest number of total tillers hill $^{-1}$ of $3.30,4.20$ and 4.45 in control at 30, 45 and 60 DAS, respectively (Table 2).

Leaf area index (LAI): The LAI was significantly affected by wheat variety and mulching at $1 \%$ level of probability at 30, 45 and 60 DAS. BARI Gom-28 produced significantly the highest LAI of $0.96,3.79$ and 6.51 at 30, 45 and 60 days after sowing, respectively. On the contrary, BARI Gom-26 gave the lowest LAI of $0.56,3.19$ and 4.94 at 30, 45 and 60 DAS, respectively (Figure 5). The highest LAl of $0.6567,3.443$ and 6.127 was observed in rice straw mulch at 30,45 and 60 DAS, respectively. On the contrary, the lowest LAI of 0.73, 3.29and 5.32was obtained from control at 30, 45 and 60 DAS, respectively (Figure 6). There was significant difference in the LAI due to interaction of variety and mulching during the growth stages of wheat at 30 and 60 DAS (Table 3). BARI Gom-28 produced the highest LAI of 1.10 and 6.88 in rice straw mulch at 30 , and 60 days after sowing, respectively. On the contrary, BARI Gom-26 gave the lowest LAI of 3.01 and 4.09 in control at 45 and 60 DAS, respectively (Table 3 ).

Chlorophyll content (SPAD value): The chlorophyll content was significantly affected by wheat variety and mulching at $1 \%$ level of probability at 30, 45 and 60 DAS. BARI Gom-28 produced significantly the highest chlorophyll content of $40.63,45.62$ and 48.41 at 30, 45 and 60 days after sowing, respectively. On the contrary, BARI Gom-26 gave the lowest chlorophyll content of $35.25,36.88$ and 38.14 at 30,45 and 60 DAS, respectively (Figure 7). The highest chlorophyll content of $39.79,42.31$ and 46.69 was observed in rice straw mulch at 30, 45 and 60 DAS, respectively. On the contrary, the lowest chlorophyll content of $34.96,39.20$ and 41.05 was obtained from control at 30, 45 and 60 DAS, respectively (Figure 8). There was significant difference in the chlorophyll content due to interaction of variety and mulching during the growth stages of wheat at 45 and 60 DAS
(Table 4). BARI Gom-28 produced the highest chlorophyll content of 55.88 in rice straw mulch at 60 DAS. On the contrary, BARI Gom-26 gave the lowest chlorophyll content of 32.30 , 33.20 and 35.20 in control at 30,45 and 60 DAS, respectively (Table 4).

Total dry matter: The total dry matter was significantly affected by wheat variety and mulching at $1 \%$ level of probability at 30 , 45 and 60 DAS. BARI Gom-28 produced significantly the highest dry matter of $1.30,6.72$ and $14.05 \mathrm{~g}$ at 30,45 and 60 days after sowing, respectively. On the contrary, BARI Gom-26 gave the lowest dry matter of 4.200, 4.017 and $9.392 \mathrm{~g}$ was found at 30, 45 and 60 DAS, respectively (Figure 9). The highest dry matter of $1.10,5.27$ and $13.11 \mathrm{~g}$ was observed in water hyacinth mulch at 30,45 and 60 DAS, respectively. On the contrary, the lowest dry matter of $.87,4.93$ and $10.67 \mathrm{~g}$ was obtained from control at 30, 45 and 60 DAS, respectively (Figure 10). There was significant difference in the total dry matter due to interaction of variety and management practices at 30, 45 and 60 DAS (Table 5). The highest total dry matter (15.80 g) was found in $\mathrm{V}_{3} \times \mathrm{M}_{3}$ and lowest total dry matter $(8.60 \mathrm{~g})$ was found in $\mathrm{V}_{1} \times \mathrm{M}_{1}$ at 60 DAS (Table 5).

\section{Yield and yield components}

Plant height $(\mathrm{cm})$ : The effect of variety and mulching on plant height was significant at $1 \%$ level of probability (Table 6 and 7). The plant height ranged from 79.36 to $91.22 \mathrm{~cm}$. The tallest plant $(91.22 \mathrm{~cm})$ was observed in BARI Gom-28 and shortest plant $(79.36 \mathrm{~cm})$ was observed in BARI Gom-26 (Table 6). This might be for the genetic make-up of the variety species. It was observed that the tallest plant $(88.36 \mathrm{~cm})$ was observed in rice straw mulch $\left(\mathrm{M}_{3}\right)$ and the shortest plant $(82.09 \mathrm{~cm})$ was observed in control $\left(M_{1}\right)$ (Table 7). There was no significant difference in the plant height due to interaction of variety and mulching (Table 8). However, numerically the tallest plant $(93.20 \mathrm{~cm}$ ) found in $\mathrm{V}_{3} \times \mathrm{M}_{3}$ and the shortest plant $(72.63 \mathrm{~cm})$ found in $\mathrm{V}_{1} \times \mathrm{M}_{1}$ (Table 8).

Number of effective tillers hill ${ }^{-1}$ : The effect of variety and mulching on number of effective tillers hill ${ }^{-1}$ was significant at $1 \%$ level of probability. The highest number of total tillers hill ${ }^{-1}$ (4.125) was observed in BARI Gom-28 $\left(\mathrm{V}_{3}\right)$ and the lowest number of total tillers hill ${ }^{-1}(2.41)$ was observed in BARI Gom-26 $\left(V_{1}\right)$ (Figure 11). It was observed that the highest number of effective tillers hill ${ }^{-1}$ (3.61) was observed in rice straw mulch $\left(\mathrm{M}_{3}\right)$ and the lowest number of effective tillers hill ${ }^{-1}$ (2.93) observed in control $\left(M_{1}\right)$ (Figure 12). There was significant difference in the number of effective tillers hill ${ }^{-1}$ due to interaction of variety and management practices (Table 8). It was observed that the highest number of effective tillers hill ${ }^{-1}$ (4.57) was observed $\mathrm{inV}_{3} \times \mathrm{M}_{3}$ and the lowest number of effective tillers hill ${ }^{-1}(2.07)$ observed in $\mathrm{V}_{1} \times \mathrm{M}_{1}$ (Table 8).

Spike length $(\mathrm{cm})$ : The effect of variety and mulching on spike length was significant (Table 6 and 7). The highest spike length 
$(9.93 \mathrm{~cm})$ was observed in BARI Gom-28 $\left(\mathrm{V}_{3}\right)$ and the lowest spike length $(9.14 \mathrm{~cm})$ was observed in BARI Gom-26 $\left(\mathrm{V}_{1}\right)($ Table 6). The possible reason may be the genetic variation among the variety. It was observed that the highest spike length $(9.81 \mathrm{~cm})$ was observed in rice straw mulch $\left(\mathrm{M}_{3}\right)$ and the lowest spike length $\left(9.23 \mathrm{~cm}\right.$ ) observed in control $\left(M_{1}\right)$ (Table 7). The spike length increased with mulching treatment. There was no significant difference in the spike length due to interaction of variety and mulching (Table 8). The highest spike length $(10.23 \mathrm{~cm})$ was obtained due to the interaction of BARI Gom-28 and rice straw mulch $\left(V_{3} \times M_{3}\right)$ and the lowest spike length $(8.43 \mathrm{~cm})$ was obtained due to the interaction of BARI Gom-26 and control $\left(\mathrm{V}_{1} \times \mathrm{M}_{1}\right)($ Table 8$)$.

Number of spikelets spike ${ }^{-1}$ : The effect of variety and mulching on number of total spikelets spike ${ }^{-1}$ was significant at $1 \%$ level of probability (Figure 13 and 14). Higher number of total spikelets spike ${ }^{-1}$ (20.11) was observed in BARI Gom-28 $\left(\mathrm{V}_{3}\right)$ and lower number of total spikelets spike ${ }^{-1}$ (15.32) was observed in BARI Gom-26 $\left(\mathrm{V}_{1}\right)$. This may be the ability of variety. It was observed that the highest number of total spikelets spike ${ }^{-1}$ (18.75) was observed in rice straw mulch $\left(\mathrm{M}_{3}\right)$ and the lowest number of total spikelets spike ${ }^{-1}$ (16.67) observed in control $\left(M_{1}\right)$ (Figure 14). The result is partially in agreement to the findings of Wang and Wang (1998) who reported that mulching accelerated greening, and increased the number of spikelets spike ${ }^{-1}$ and number spike ${ }^{-1}$. Number of total spikelets spike ${ }^{-1}$ was significantly influenced by the interaction of variety and (Table 8). The highest no of spikelets spike ${ }^{-1}$ (21.15) was obtained due to the interaction of BARI Gom-28 and rice straw mulch $\left(\mathrm{V}_{3} \times \mathrm{M}_{3}\right)$ and the lowest no of spikelets spike ${ }^{-1}$ (14.37) was obtained due to the interaction of BARI Gom-26 and control $\left(\mathrm{V}_{1} \times \mathrm{M}_{1}\right)$ (Table 8). Rahman et al. (2005) reported straw mulch treatments brought about significantly higher spikes per unit area and kernel weight per spike than no-mulch treatment, but not in kernel weight.

Number of seeds spike ${ }^{-1}$ : The effect of variety and mulching on number of seeds spike ${ }^{-1}$ was significant at $1 \%$ level of probability (Table 6 and 7). The highest number of seeds spike ${ }^{-1}$ (50.90) was observed in BARI Gom-28 $\left(\mathrm{V}_{3}\right)$ and the lowest number of seeds spike ${ }^{-1}$ (38.33) was observed in BARI Gom-26 $\left(V_{1}\right)$ (Table 6). It was observed that the highest number of seeds spike ${ }^{-1}$ (47.05) was observed in rice straw mulch $\left(M_{3}\right)$ and the lowest number of seeds spike ${ }^{-1}(41.30)$ observed in control $\left(M_{1}\right)$ (Table 7). There was significant difference in the number of seeds spike ${ }^{-1}$ due to interaction of variety and mulching (Table 8 ). The difference was significant at $1 \%$ level of probability. The highest number of seeds spike ${ }^{-1}$ (54.68) was obtained due to the interaction of BARI Gom-28 and rice straw mulch $\left(\mathrm{V}_{3} \times \mathrm{M}_{3}\right)$ and the lowest number of seeds spike ${ }^{-1}$ (35.40) was obtained due to the interaction of BARI Gom-26 and control $\left(\mathrm{V}_{1} \times \mathrm{M}_{1}\right)$ (Table 8).

1000-grain weight: Variety and mulching showed significant effect on 1000-grain weight at $1 \%$ level of probability (Table 6 and 7). The highest 1000 -grain weight ( $47.04 \mathrm{~g}$ ) was observed in BARI Gom-28 $\left(\mathrm{V}_{3}\right)$ and the lowest 1000-grain weight (36.32 g) was observed in BARI Gom-26 $\left(\mathrm{V}_{1}\right)$ (Table 6). It was observed that the highest 1000-grain weight (44.20 g) was observed in rice straw mulch $\left(\mathrm{M}_{3}\right)$ treatment and the lowest 1000-grain weight $(39.50 \mathrm{~g})$ observed in control $\left(\mathrm{M}_{1}\right)$. Weight of 1000 grains was not significantly influenced by the interaction of variety and mulching (Table 8). It was observed that the highest 1000 -grain weight $(48.54 \mathrm{~g})$ was observed in $\left(\mathrm{V}_{3} \times \mathrm{M}_{3}\right)$ treatment and the lowest 1000 -grain weight ( $32.00 \mathrm{~g})$ observed in $\left(V_{1} \times M_{1}\right)$ (Table 8).

Grain yield: Grain yield had significant effect with variety and mulching at $1 \%$ level of probability (Figure 15 and 16). The highest grain yield $\left(4.7 \mathrm{tha}^{-1}\right)$ was observed in BARI Gom-28 $\left(\mathrm{V}_{3}\right)$ and the lowest grain yield $\left(3.23 \mathrm{t} \mathrm{ha}^{-1}\right)$ was observed in BARI Gom$26\left(V_{1}\right)$ (Figure 15). These differences may be due to variation in response to variety and environmental condition at the experimental site. It was observed that the highest grain yield $(4.27 \mathrm{t}$ $\mathrm{ha}^{-1}$ ) was observed in rice straw mulch $\left(\mathrm{M}_{3}\right)$ treatment and the lowest grain yield $\left(3.53 \mathrm{t} \mathrm{ha}^{-1}\right.$ ) observed in control $\left(\mathrm{M}_{1}\right)$ (Figure 16). Similar results were observed by Sachan (1976), De et al. (1983), Chen (1996) and Upadhyay and Tiwari (1996). Authors observed that mulching with rice straw significantly increased the yields of wheat. There was significant difference in the grain yield due to interaction of variety and mulching (Table 8 ). The highest yield $\left(5.20 \mathrm{t} \mathrm{ha}^{-1}\right)$ was obtained due to the interaction of BARI Gom-28 and rice straw mulch $\left(\mathrm{V}_{3} \times \mathrm{M}_{3}\right)$ and the lowest grain yield $\left(2.87 \mathrm{t} \mathrm{ha}^{-1}\right)$ was obtained due to the interaction of BARI Gom-26 and control $\left(V_{1} \times M_{1}\right)$ (Table 8). This variation may be due to variation in response to variety and grain yield. Zamir et al. (2013) also reported similar findings and stated that the wheat straw mulch gave highest grain yield $\left(6.33 \mathrm{t} \mathrm{ha}^{-1}\right)$, followed by sawdust $\left(4.92 \mathrm{tha}^{-1}\right)$.

Straw yield: The effect of variety and mulching on straw yield was significant at $1 \%$ level of probability (Figure 17 and 18). The highest straw yield $\left(6.89 \mathrm{t} \mathrm{ha}^{-1}\right)$ was observed in BARI Gom-28 $\left(V_{3}\right)$ and the lowest straw yield $\left(5.01 \mathrm{t} \mathrm{ha}^{-1}\right)$ was observed in BARI Gom-26( $\left.\mathrm{V}_{1}\right)$ (Figure 17). The highest straw yield (6.26 t ha $\left.{ }^{1}\right)$ was observed in rice straw mulch $\left(M_{3}\right)$ and the lowest straw yield (5.45 t ha ${ }^{-1}$ ) was observed in control $\left(M_{1}\right)$ (Figure 18). The result was partially similar to the findings of Sharma et al. (1998). They found that application of increased moisture extraction, water use efficiency and grain and straw yields of wheat. Straw yield was significant at $1 \%$ level of probability with the interaction effect of variety and mulching (Table 8 ). The highest straw yield $\left(7.27 \mathrm{t} \mathrm{ha}^{-1}\right)$ was obtained in the interaction of BARI Gom28 and rice straw mulch $\left(\mathrm{V}_{3} \times \mathrm{M}_{3}\right)$ and the lowest straw yield $\left(4.70 \mathrm{t} \mathrm{ha}^{-1}\right)$ was obtained in the interaction of BARI Gom-26 and control $\left(\mathrm{V}_{1} \times \mathrm{M}_{1}\right)$ (Table 8).

Harvest index (\%): The effect of variety and mulching on harvest index was significant (Table 6 and 7). The highest harvest index (40.49\%) was observed in BARI Gom-28 $\left(\mathrm{V}_{3}\right)$ and the lowest harvest index (39.17) was observed in BARI Gom-26 $\left(V_{1}\right)$ (Table 6). It was observed that the highest harvest index $(40.46 \%)$ was observed in rice straw mulch $\left(M_{3}\right)$ and the lowest 
harvest index (39.21\%) observed in control $\left(\mathrm{M}_{1}\right)$ (Table 7). Variety and mulching interacted not significantly for harvest index (Table 8). But numerically, the highest harvest index (41.71\%) was obtained due to the interaction of BARI Gom-28 and rice straw mulch $\left(V_{3} \times M_{3}\right)$. The lowest harvest index (37.91\%) was obtained due to the interaction of BARI Gom-26 and control $\left(V_{1} \times M_{1}\right)$.

Table 1. Interaction effects of variety and mulching on plant height at different days after sowing of wheat.

\begin{tabular}{|c|c|c|c|}
\hline \multirow{3}{*}{ Interaction (Variety $\times$ mulching) } & \multicolumn{3}{|c|}{ Plant height $(\mathrm{cm})$} \\
\hline & \multicolumn{3}{|c|}{ Days after sowing (DAS) } \\
\hline & 30 & 45 & 60 \\
\hline $\mathrm{V}_{1 \times} \mathrm{M}_{1}$ & 27.50 & $40.80 f$ & $69.20 \mathrm{~h}$ \\
\hline $\mathrm{V}_{1 \times} \mathrm{M}_{2}$ & 29.88 & $43.70 \mathrm{de}$ & 73.30fgh \\
\hline $\mathrm{V}_{1 \times} \mathrm{M}_{3}$ & 30.50 & $45.67 d$ & 76.40efg \\
\hline $\mathrm{V}_{1 \times} \mathrm{M}_{4}$ & 28.40 & 42.70ef & 71.60gh \\
\hline $\mathrm{V}_{2 \times} \mathrm{M}_{1}$ & 30.20 & $49.80 c$ & 75.50 efg \\
\hline $\mathrm{V}_{2 \times} \mathrm{M}_{2}$ & 34.80 & $51.2 \mathrm{c}$ & 79.20de \\
\hline $\mathrm{V}_{2 \times} \mathrm{M}_{3}$ & 35.40 & $50.50 \mathrm{c}$ & $83.40 \mathrm{~cd}$ \\
\hline $\mathrm{V}_{2 \times} \mathrm{M}_{4}$ & 32.40 & $50.67 c$ & $78.20 \mathrm{ef}$ \\
\hline $\mathrm{V}_{3 \times} \mathrm{M}_{1}$ & 35.43 & $65.50 a$ & $70.2 \mathrm{~h}$ \\
\hline $\mathrm{V}_{3 \times} \mathrm{M}_{2}$ & 36.83 & $60.20 \mathrm{~b}$ & 89.83ab \\
\hline $\mathrm{V}_{3 \times} \mathrm{M}_{3}$ & 38.87 & $65.65 a$ & $91.07 a$ \\
\hline $\mathrm{V}_{3 \times} \mathrm{M}_{4}$ & 36.20 & $60.89 b$ & $85.50 \mathrm{bc}$ \\
\hline $\mathrm{LSD}_{0.05}$ & 2.15 & 2.71 & 4.66 \\
\hline Level of sig. & NS & ** & ** \\
\hline CV (\%) & 3.88 & 3.07 & 3.50 \\
\hline
\end{tabular}

In a column, figures with same letter (s) or without letter do not differ significantly whereas figures with dissimilar letter differ significantly (as per DMRT); ${ }^{* *}=$ Significant at $5 \%$ level of probability, NS = Not significant; $\mathrm{V}_{1^{-}}=\mathrm{BARI}$ Gom-26, $\mathrm{V}_{2^{-}}=$BARI Gom-27, $\mathrm{V}_{3^{-}}=\mathrm{BARI}$ Gom-28 M $\mathrm{M}_{1}=$ no mulch + no irrigation; $M_{2}=$ mulching with water hyacinth + no irrigation; $M_{3}=$ mulching with rice straw + no irrigation; $M_{4}=$ two irrigation at $C R I$ and flowering stage.

Table 2. Interaction effects of variety and mulching on number of total tillers hill ${ }^{-1}$ at different days after sowing of wheat.

\begin{tabular}{|c|c|c|c|}
\hline \multirow{3}{*}{ Interaction (Variety $\times$ mulching) } & \multicolumn{3}{|c|}{ No. of total tillers hill ${ }^{-1}$} \\
\hline & \multicolumn{3}{|c|}{ Days after sowing (DAS) } \\
\hline & 30 & 45 & 60 \\
\hline $\mathrm{V}_{1 \times} \mathrm{M}_{1}$ & $3.30 \mathrm{f}$ & $4.20 \mathrm{f}$ & $4.45 \mathrm{e}$ \\
\hline $\mathrm{V}_{1 \times} \mathrm{M}_{2}$ & 3.41def & $4.45 \mathrm{def}$ & $4.76 \mathrm{de}$ \\
\hline $\mathrm{V}_{1 \times} \mathrm{M}_{3}$ & 3.44def & 4.47def & $4.88 \mathrm{~cd}$ \\
\hline $\mathrm{V}_{1 \times} \mathrm{M}_{4}$ & 3.39ef & 4.41ef & 4.72de \\
\hline$V_{2 \times} M_{1}$ & 3.47def & $4.50 \mathrm{def}$ & $4.92 \mathrm{~cd}$ \\
\hline $\mathrm{V}_{2 \times} \mathrm{M}_{2}$ & $3.60 \mathrm{bcd}$ & 4.69cde & $5.10 \mathrm{c}$ \\
\hline $\mathrm{V}_{2 \times} \mathrm{M}_{3}$ & $3.68 b c$ & $4.75 \mathrm{~cd}$ & $5.15 c$ \\
\hline $\mathrm{V}_{2 \times} \mathrm{M}_{4}$ & $3.56 \mathrm{cde}$ & 4.65 cde & $4.98 \mathrm{~cd}$ \\
\hline$V_{3 \times} M_{1}$ & $3.77 a b$ & $4.83 c$ & $5.20 c$ \\
\hline $\mathrm{V}_{3 \times} \mathrm{M}_{2}$ & $3.87 \mathrm{a}$ & $5.23 b$ & $6.50 \mathrm{a}$ \\
\hline$V_{3 \times} M_{3}$ & $3.60 \mathrm{bcd}$ & $5.73 a$ & $6.75 a$ \\
\hline$V_{3 \times} M_{4}$ & $3.53 \mathrm{cde}$ & $5.44 \mathrm{~b}$ & $5.65 b$ \\
\hline $\mathrm{LSD}_{0.05}$ & 0.16 & 0.27 & 0.30 \\
\hline Level of sig. & $* *$ & * & $* *$ \\
\hline CV (\%) & 2.81 & 3.47 & 3.46 \\
\hline
\end{tabular}

In a column, figures with same letter (s) or without letter do not differ significantly whereas figures with dissimilar letter differ significantly (as per DMRT); ${ }^{*}=$ Significant at $5 \%$ level of probability, ${ }^{* *}=$ Significant at $1 \%$ level of probability, NS = Not significant; $\mathrm{V}_{1^{-}}=$BARI Gom-26, $\mathrm{V}_{2^{-}}=\mathrm{BARI}$ Gom-27, $V_{3^{-}}=$BARI Gom-28; $M_{1}=$ no mulch + no irrigation; $M_{2}=$ mulching with water hyacinth + no irrigation; $M_{3}=$ mulching with rice straw + no irrigation; $\mathrm{M}_{4}=$ two irrigation at $\mathrm{CRI}$ and flowering stage. 
Table 3. Interaction effects of variety and mulching on leaf area index at different days after sowing of wheat.

\begin{tabular}{|c|c|c|c|}
\hline \multirow{3}{*}{ Interaction (Variety × mulching) } & \multicolumn{3}{|c|}{ Leaf area index (LAI) } \\
\hline & \multicolumn{3}{|c|}{ Days after sowing (DAS) } \\
\hline & 30 & 45 & 60 \\
\hline $\mathrm{V}_{1 \times} \mathrm{M}_{1}$ & $0.83 b c$ & 3.01 & $4.09 \mathrm{~h}$ \\
\hline $\mathrm{V}_{1 \times} \mathrm{M}_{2}$ & $0.48 \mathrm{fg}$ & 3.25 & $5.20 \mathrm{fg}$ \\
\hline $\mathrm{V}_{1 \times} \mathrm{M}_{3}$ & $0.55 f$ & 3.33 & 5.50ef \\
\hline $\mathrm{V}_{1 \times} \mathrm{M}_{4}$ & $0.40 \mathrm{~g}$ & 3.20 & $4.97 \mathrm{~g}$ \\
\hline$V_{2 \times} M_{1}$ & $0.60 \mathrm{ef}$ & 3.31 & $5.68 \mathrm{de}$ \\
\hline $\mathrm{V}_{2 \times} \mathrm{M}_{2}$ & $0.72 \mathrm{cde}$ & 3.44 & $5.88 \mathrm{cde}$ \\
\hline $\mathrm{V}_{2 \times} \mathrm{M}_{3}$ & $0.75 c d$ & 3.50 & $6.00 \mathrm{~cd}$ \\
\hline $\mathrm{V}_{2 \times} \mathrm{M}_{4}$ & $0.69 \mathrm{de}$ & 3.37 & $5.76 \mathrm{de}$ \\
\hline$V_{3 \times} M_{1}$ & $0.78 \mathrm{bcd}$ & 3.56 & $6.20 b c$ \\
\hline $\mathrm{V}_{3 \times} \mathrm{M}_{2}$ & $1.09 a$ & 3.96 & $6.55 \mathrm{ab}$ \\
\hline $\mathrm{V}_{3 \times} \mathrm{M}_{3}$ & $1.10 a$ & 3.87 & $6.88 a$ \\
\hline$V_{3 \times} M_{4}$ & $0.88 \mathrm{~b}$ & 3.76 & $6.44 b$ \\
\hline LSD $_{0.05}$ & 0.11 & 0.21 & 0.38 \\
\hline Level of sig. & ** & NS & $* *$ \\
\hline CV (\%) & 9.43 & 3.64 & 4.01 \\
\hline
\end{tabular}

In a column, figures with same letter (s) or without letter do not differ significantly whereas figures with dissimilar letter differ significantly (as per DMRT); ${ }^{* *}=$ Significant at $1 \%$ level of probability, NS = Not significant; $\mathrm{V}_{1^{-}}=$BARI Gom-26, $\mathrm{V}_{2^{-}}=$BARI Gom-27, $\mathrm{V}_{3^{-}}=\mathrm{BARI}$ Gom- $28 \mathrm{M} \mathrm{M}_{1}=$ no mulch + no irrigation; $M_{2}=$ mulching with water hyacinth + no irrigation; $M_{3}=$ mulching with rice straw + no irrigation; $M_{4}=$ two irrigation at $C R I$ and flowering stage.

Table 4. Interaction effects of variety and mulching on chlorophyll content at different days after sowing of wheat.

\begin{tabular}{|c|c|c|c|}
\hline \multirow{3}{*}{ Interaction (Variety $\times$ mulching) } & \multicolumn{3}{|c|}{ Chlorophyll content } \\
\hline & \multicolumn{3}{|c|}{ Days after sowing (DAS) } \\
\hline & 30 & 45 & 60 \\
\hline$V_{1 \times} M_{1}$ & 32.30 & $33.20 \mathrm{~h}$ & $35.20 \mathrm{e}$ \\
\hline $\mathrm{V}_{1 \times} \mathrm{M}_{2}$ & 36.20 & $38.50 f g$ & $39.20 d$ \\
\hline $\mathrm{V}_{1 \times} \mathrm{M}_{3}$ & 37.20 & $39.40 \mathrm{ef}$ & $40.40 \mathrm{~cd}$ \\
\hline $\mathrm{V}_{1 \times} \mathrm{M}_{4}$ & 35.30 & $36.40 \mathrm{~g}$ & 37.77de \\
\hline $\mathrm{V}_{2 \times} \mathrm{M}_{1}$ & 35.97 & 40.07def & $41.47 \mathrm{~cd}$ \\
\hline $\mathrm{V}_{2 \times} \mathrm{M}_{2}$ & 38.40 & 41.30de & $41.70 \mathrm{~cd}$ \\
\hline $\mathrm{V}_{2 \times} \mathrm{M}_{3}$ & 39.28 & $42.30 \mathrm{~cd}$ & $43.80 b c$ \\
\hline $\mathrm{V}_{2 \times} \mathrm{M}_{4}$ & 37.23 & 40.40def & $41.60 \mathrm{~cd}$ \\
\hline $\mathrm{V}_{3 \times} \mathrm{M}_{1}$ & 36.60 & $44.33 b c$ & 46.47b \\
\hline $\mathrm{V}_{3 \times} \mathrm{M}_{2}$ & 42.70 & $48.70 a$ & $45.55 b$ \\
\hline $\mathrm{V}_{3 \times} \mathrm{M}_{3}$ & 42.88 & $45.23 b$ & $55.88 a$ \\
\hline $\mathrm{V}_{3 \times} \mathrm{M}_{4}$ & 40.33 & $44.20 b c$ & $45.75 b$ \\
\hline LSD $_{0.05}$ & 2.59 & 2.37 & 3.54 \\
\hline Level of sig. & NS & $* *$ & $* *$ \\
\hline CV (\%) & 4.04 & 3.41 & 4.88 \\
\hline
\end{tabular}

In a column, figures with same letter (s) or without letter do not differ significantly whereas figures with dissimilar letter differ significantly (as per DMRT); ${ }^{* *}=$ Significant at $1 \%$ level of probability, NS = Not significant; $\mathrm{V}_{1^{-}}=$BARI Gom-26, $\mathrm{V}_{2^{-}}=$BARI Gom-27, $\mathrm{V}_{3^{-}}=$BARI Gom-28 M ${ }_{1}=$ no mulch + no irrigation; $M_{2}=$ mulching with water hyacinth + no irrigation; $M_{3}=$ mulching with rice straw + no irrigation; $M_{4}=$ two irrigation at $C R I$ and flowering stage.

Table 5. Interaction effects of variety and mulching on total dry matter at different days after sowing of wheat.

\begin{tabular}{|c|c|c|c|}
\hline \multirow{3}{*}{ Interaction (Variety $\times$ mulching) } & \multicolumn{3}{|c|}{ Total dry matter (g) } \\
\hline & \multicolumn{3}{|c|}{ Days after sowing (DAS) } \\
\hline & 30 & 45 & 60 \\
\hline $\mathrm{V}_{1 \times} \mathrm{M}_{1}$ & $0.74 f$ & $4.04 \mathrm{ef}$ & $8.60 \mathrm{~g}$ \\
\hline $\mathrm{V}_{1 \times} \mathrm{M}_{2}$ & $0.70 f$ & $4.05 \mathrm{ef}$ & $9.65 \mathrm{ef}$ \\
\hline $\mathrm{V}_{1 \times} \mathrm{M}_{3}$ & $0.76 \mathrm{ef}$ & $4.10 \mathrm{ef}$ & $9.88 \mathrm{ef}$ \\
\hline $\mathrm{V}_{1 \times} \mathrm{M}_{4}$ & $0.68 \mathrm{f}$ & $3.88 \mathrm{f}$ & $9.44 f$ \\
\hline $\mathrm{V}_{2 \times} \mathrm{M}_{1}$ & $0.88 \mathrm{de}$ & $4.20 \mathrm{de}$ & $10.44 \mathrm{e}$ \\
\hline $\mathrm{V}_{2 \times} \mathrm{M}_{2}$ & $0.99 d$ & $4.86 c$ & $13.26 c$ \\
\hline $\mathrm{V}_{2 \times} \mathrm{M}_{3}$ & $0.96 \mathrm{~d}$ & $4.85 c$ & $13.64 b c$ \\
\hline $\mathrm{V}_{2 \times} \mathrm{M}_{4}$ & $0.87 \mathrm{de}$ & $4.44 d$ & $11.65 d$ \\
\hline$V_{3 \times} M_{1}$ & $1.00 \mathrm{~d}$ & $6.55 b$ & $12.96 c$ \\
\hline $\mathrm{V}_{3 \times} \mathrm{M}_{2}$ & $1.40 \mathrm{~b}$ & $6.76 a b$ & $14.30 \mathrm{~b}$ \\
\hline $\mathrm{V}_{3 \times} \mathrm{M}_{3}$ & $1.60 a$ & $6.88 a$ & $15.80 \mathrm{a}$ \\
\hline $\mathrm{V}_{3 \times} \mathrm{M}_{4}$ & $1.20 c$ & $6.70 a b$ & $13.15 c$ \\
\hline $\mathrm{LSD}_{0.05}$ & 0.11 & 0.28 & 0.79 \\
\hline Level of sig. & $* *$ & $*$ & $* *$ \\
\hline CV (\%) & 7.29 & 3.28 & 3.93 \\
\hline
\end{tabular}

In a column, figures with same letter (s) or without letter do not differ significantly whereas figures with dissimilar letter differ significantly (as per $\mathrm{DMRT}){ }^{*}=$ Significant at $5 \%$ level of probability, ${ }^{* *}=$ Significant at $1 \%$ level of probability; NS = Not significant; $\mathrm{V}_{1^{-}}=\mathrm{BARI}$ Gom-26, $\mathrm{V}_{2^{-}}=\mathrm{BARI}$ Gom-27, $V_{3^{-}}=$BARI Gom-28; $M_{1}=$ no mulch + no irrigation; $M_{2}=$ mulching with water hyacinth + no irrigation; $M_{3}=$ mulching with rice straw + no irrigation; $\mathrm{M}_{4}=$ two irrigation at $\mathrm{CRI}$ and flowering stage. 
Table 6. Effect of variety on yield and yield contributing characters of wheat.

\begin{tabular}{|c|c|c|c|c|c|}
\hline Variety & $\begin{array}{l}\text { Plant height } \\
(\mathrm{cm})\end{array}$ & $\begin{array}{l}\text { Spike length } \\
\text { (cm) }\end{array}$ & $\begin{array}{l}\text { No. of seeds } \\
\text { spike }^{-1}\end{array}$ & $\begin{array}{c}1000 \text { seed weight } \\
\text { (g) }\end{array}$ & $\begin{array}{c}\text { Harvest Index } \\
\text { (\%) }\end{array}$ \\
\hline BARI Gom 26 & $79.36 c$ & $9.14 b$ & $38.33 c$ & $36.32 c$ & $39.17 b$ \\
\hline BARI Gom 27 & $86.51 b$ & $9.63 a$ & $43.90 b$ & $42.79 b$ & $40.10 a$ \\
\hline BARI Gom 28 & $91.22 \mathrm{a}$ & $9.93 a$ & $50.90 a$ & $47.04 a$ & $40.49 a$ \\
\hline $\mathrm{LSD}_{0.05}$ & 2.66 & 0.30 & 0.76 & 1.10 & 0.71 \\
\hline Level of significance & $* *$ & $* *$ & $* *$ & $* *$ & $* *$ \\
\hline CV (\%) & 3.67 & 3.75 & 2.03 & 3.10 & 2.12 \\
\hline
\end{tabular}

In a column, figures with same letter (s) or without letter do not differ significantly whereas figures with dissimilar letter differ significantly (as per $\mathrm{DMRT}^{* *}=$ Significant at $1 \%$ level of probability.

Table 7. Effect of mulching on yield and yield contributing characters of wheat.

\begin{tabular}{|c|c|c|c|c|c|}
\hline Mulching & $\begin{array}{l}\text { Plant height } \\
(\mathrm{cm})\end{array}$ & $\begin{array}{l}\text { Spike length } \\
\text { (cm) }\end{array}$ & No. of seeds spike & $\begin{array}{c}1000 \text { seed weight } \\
\text { (g) }\end{array}$ & $\begin{array}{c}\text { Harvest Index } \\
\text { (\%) }\end{array}$ \\
\hline$M_{1}$ & $82.09 b$ & $9.23 b$ & $41.30 d$ & $39.50 c$ & $39.21 b$ \\
\hline$M_{2}$ & $86.71 \mathrm{a}$ & $9.68 a$ & $45.43 b$ & $43.04 a$ & $40.17 a$ \\
\hline$M_{3}$ & $88.36 a$ & $9.81 a$ & $47.05 a$ & $44.20 \mathrm{a}$ & $40.46 a$ \\
\hline$M_{4}$ & $85.63 a$ & 9.54ab & $43.73 c$ & $41.47 b$ & $39.83 a b$ \\
\hline LSD $_{0.05}$ & 3.07 & 0.35 & 0.88 & 1.27 & 0.82 \\
\hline Level of significance & $* *$ & $* *$ & $* *$ & $* *$ & $*$ \\
\hline CV (\%) & 3.67 & 3.75 & 2.03 & 3.10 & 2.12 \\
\hline
\end{tabular}

In a column, figures with same letter (s) or without letter do not differ significantly whereas figures with dissimilar letter differ significantly (as per $\mathrm{DMRT}^{* *}=$ Significant at $1 \%$ level of probability, ${ }^{*}=$ Significant at $5 \%$ level of probability; $M_{1}=$ no mulch + no irrigation; $M_{2}=$ mulching with water hyacinth + no irrigation, $M_{3}=$ mulching with rice straw + no irrigation, $M_{4}=$ two irrigation at CRI and flowering stage.

Table 8. Interaction effects of variety and mulching on yield and yield contributing characters of wheat.

\begin{tabular}{|c|c|c|c|c|c|c|c|c|c|}
\hline $\begin{array}{l}\text { Interaction } \\
\text { (Variety x mulching) }\end{array}$ & $\begin{array}{c}\text { Plant } \\
\text { height } \\
\text { (cm) }\end{array}$ & $\begin{array}{l}\text { No. of } \\
\text { effective } \\
\text { tiller hill }\end{array}$ & $\begin{array}{c}\text { Spike } \\
\text { length } \\
\text { (cm) }\end{array}$ & $\begin{array}{l}\text { No. of } \\
\text { spikelets } \\
\text { spike }^{-1}\end{array}$ & $\begin{array}{l}\text { No. of } \\
\text { seeds } \\
\text { spike }^{-1}\end{array}$ & $\begin{array}{c}1000 \\
\text { seed } \\
\text { weight (g) }\end{array}$ & $\begin{array}{c}\text { Grain } \\
\text { yield } \\
\left(\mathrm{t} \mathrm{ha}^{-1}\right)\end{array}$ & $\begin{array}{c}\text { Straw } \\
\text { yield } \\
\left(\mathrm{t} \mathrm{ha}^{-1}\right)\end{array}$ & $\begin{array}{c}\text { Harvest } \\
\text { Index } \\
(\%)\end{array}$ \\
\hline $\mathrm{V}_{1 \times} \mathrm{M}_{1}$ & 72.63 & 2.071 & 8.43 & $14.37 \mathrm{~h}$ & $35.40 \mathrm{j}$ & 32.00 & $2.87 \mathrm{~h}$ & $4.70 f$ & 37.91 \\
\hline $\mathrm{V}_{1 \times} \mathrm{M}_{2}$ & 81.57 & $2.53 \mathrm{j}$ & 9.43 & $15.69 \mathrm{fg}$ & 39.33hi & 37.96 & $3.40 f$ & $5.18 \mathrm{e}$ & 39.62 \\
\hline $\mathrm{V}_{1 \times} \mathrm{M}_{3}$ & 83.37 & $2.73 i$ & 9.47 & $15.92 \mathrm{fg}$ & 40.73gh & 39.40 & $3.50 f$ & $5.27 \mathrm{e}$ & 39.91 \\
\hline $\mathrm{V}_{1 \times} \mathrm{M}_{4}$ & 79.87 & $2.33 \mathrm{k}$ & 9.24 & $15.30 \mathrm{~g}$ & $37.87 i$ & 35.93 & $3.17 \mathrm{~g}$ & $4.91 f$ & 39.23 \\
\hline$V_{2 \times} M_{1}$ & 84.50 & $2.93 \mathrm{~h}$ & 9.52 & $16.23 f$ & $41.71 \mathrm{~g}$ & 41.10 & $3.53 f$ & $5.32 \mathrm{e}$ & 39.91 \\
\hline $\mathrm{V}_{2 \times} \mathrm{M}_{2}$ & 87.03 & $3.33 f$ & 9.68 & $18.73 d$ & 44.67 ef & 43.39 & 4.00de & $5.90 d$ & 40.41 \\
\hline $\mathrm{V}_{2 \times} \mathrm{M}_{3}$ & 88.50 & $3.53 e$ & 9.73 & $19.17 \mathrm{~cd}$ & $45.73 \mathrm{de}$ & 44.66 & 4.13de & $6.26 c$ & 39.76 \\
\hline $\mathrm{V}_{2 \times} \mathrm{M}_{4}$ & 86.00 & $3.13 g$ & 9.61 & $17.60 \mathrm{e}$ & $43.47 f$ & 42.00 & $3.93 e$ & $5.82 d$ & 40.34 \\
\hline $\mathrm{V}_{3 \times} \mathrm{M}_{1}$ & 89.15 & $3.80 \mathrm{~d}$ & 9.76 & $19.40 \mathrm{bcd}$ & $46.80 \mathrm{~d}$ & 45.40 & $4.20 \mathrm{~d}$ & $6.35 c$ & 39.81 \\
\hline $\mathrm{V}_{3 \times} \mathrm{M}_{2}$ & 91.53 & $4.13 b$ & 9.95 & $20.19 b$ & $52.28 b$ & 47.77 & $4.90 \mathrm{~b}$ & $7.20 \mathrm{a}$ & 40.49 \\
\hline $\mathrm{V}_{3 \times} \mathrm{M}_{3}$ & 93.20 & $4.57 \mathrm{a}$ & 10.23 & $21.15 \mathrm{a}$ & $54.68 \mathrm{a}$ & 48.54 & $5.20 \mathrm{a}$ & $7.27 \mathrm{a}$ & 41.71 \\
\hline $\mathrm{V}_{3 \times} \mathrm{M}_{4}$ & 91.01 & $4.00 \mathrm{c}$ & 9.80 & $19.70 \mathrm{bc}$ & $49.84 \mathrm{c}$ & 46.47 & $4.50 \mathrm{c}$ & $6.77 \mathrm{~b}$ & 39.93 \\
\hline $\mathrm{LSD}_{0.05}$ & 5.32 & 0.09 & 0.60 & 0.76 & 1.52 & 2.20 & 0.20 & 0.21 & 1.43 \\
\hline $\mathrm{Sx}$ & 1.81 & 0.03 & 0.20 & 0.26 & 0.52 & 0.75 & 0.07 & 0.07 & 0.48 \\
\hline Level of sig. & NS & $*$ & NS & $*$ & $*$ & NS & $*$ & $*$ & NS \\
\hline CV (\%) & 3.67 & 1.70 & 3.75 & 2.54 & 2.03 & 3.10 & 3.09 & 2.16 & 2.12 \\
\hline
\end{tabular}

In a column, figures with same letter (s) or without letter do not differ significantly whereas figures with dissimilar letter differ significantly (as per $\mathrm{DMRT}^{*}=$ Significant at $5 \%$ level of probability, NS = Not significant; $\mathrm{V}_{1^{-}}=$BARI Gom-26, $\mathrm{V}_{2^{-}}=$BARI Gom-27, $\mathrm{V}_{3^{-}}=$BARI Gom-28; $\mathrm{M}_{1}=$ no mulch + no irrigation $M_{2}=$ mulching with water hyacinth + no irrigation; $M_{3}=$ mulching with rice straw + no irrigation $M_{4}=$ two irrigation at $C R I$ and flowering stage. 


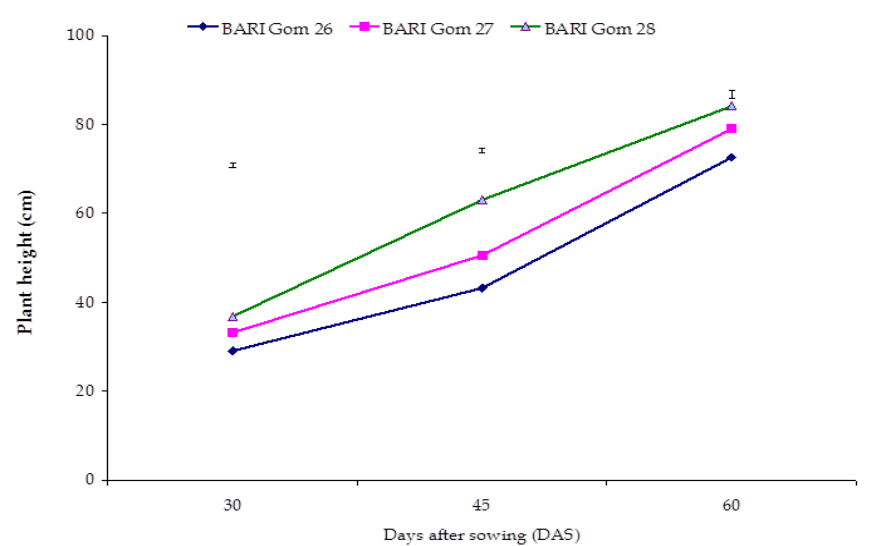

Figure 1. Effect of variety on plant height at different DAS of wheat.

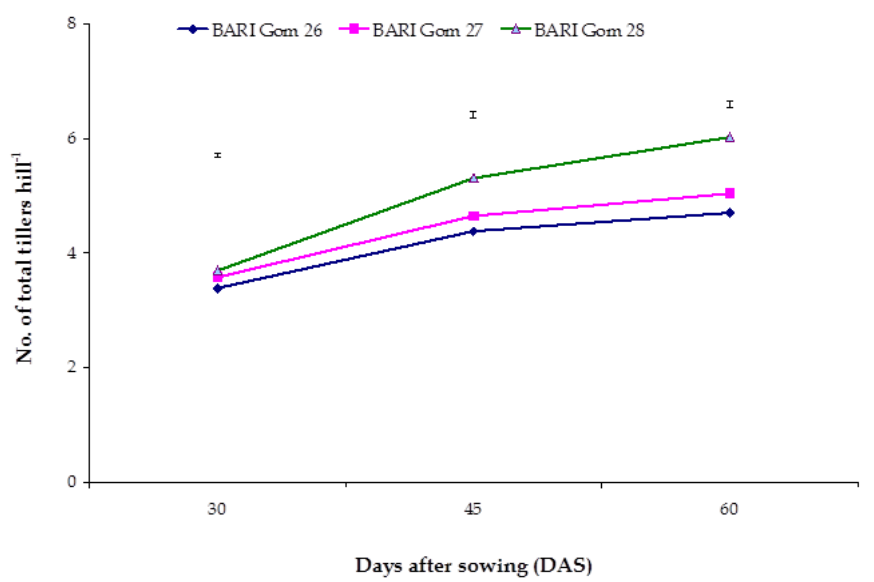

Figure 3. Effect of variety on number of total tillers hill ${ }^{-1}$ at different DAS of wheat.

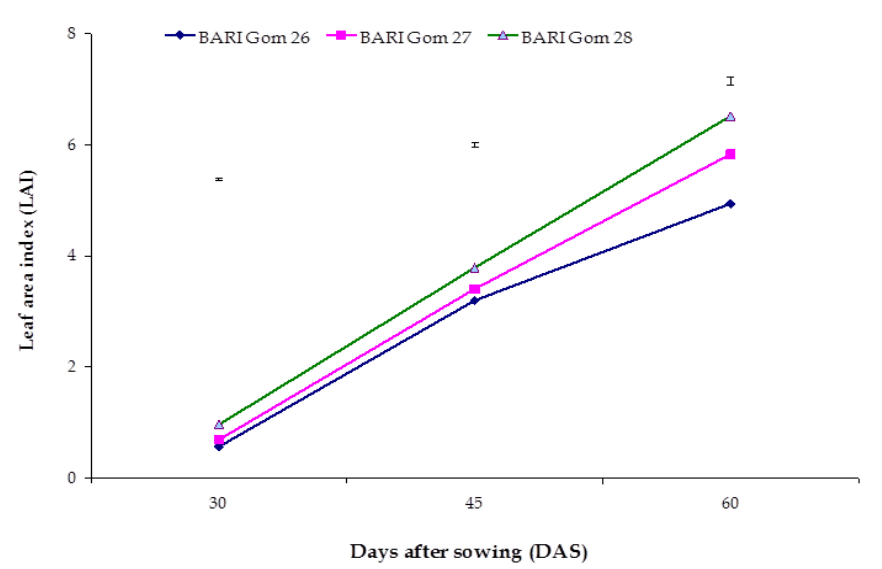

Figure 5. Effect of variety on leaf area index (LAI) at different DAS of wheat.

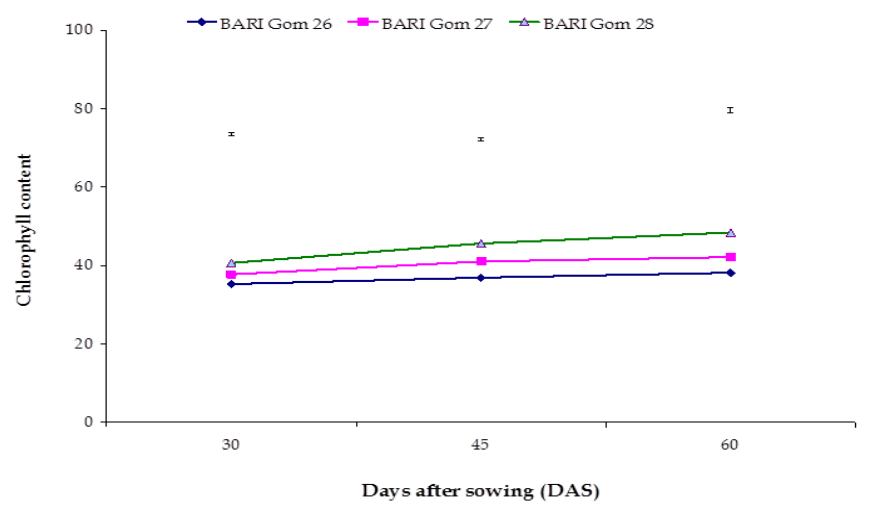

Figure 7. Effect of variety on chlorophyll content at different DAS of wheat.

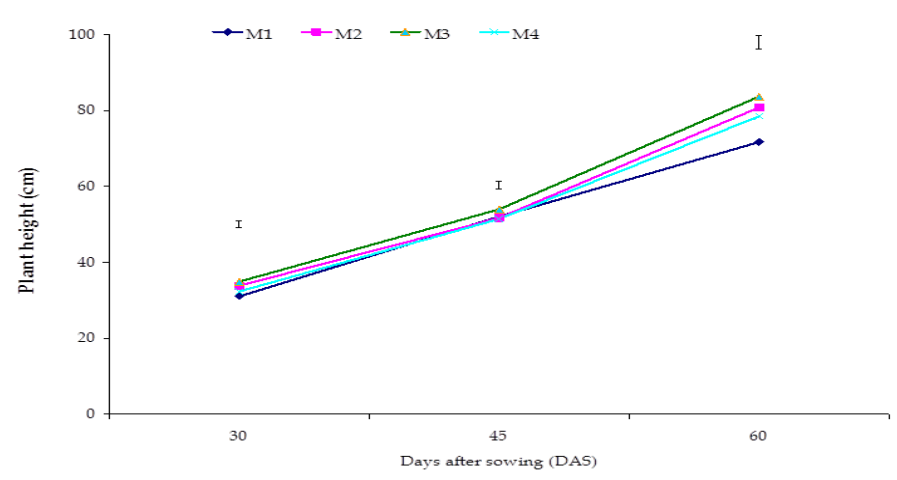

Figure 2. Effect of mulching on plant height at different DAS of wheat $\left(M_{1}\right.$ = control, $M_{2}=$ mulching with water hyacinth, $M_{3}=$ mulching with rice straw, $M_{4}=$ two irrigations at CRI and flowering stage).



Figure 4. Effect of mulching on number of total tillers hill ${ }^{-1}$ at different DAS of wheat $\left(M_{1}=\right.$ control, $M_{2}=$ mulching with water hyacinth, $M_{3}=$ mulching with rice straw, $M_{4}=$ two irrigations at $C R I$ and flowering stage).

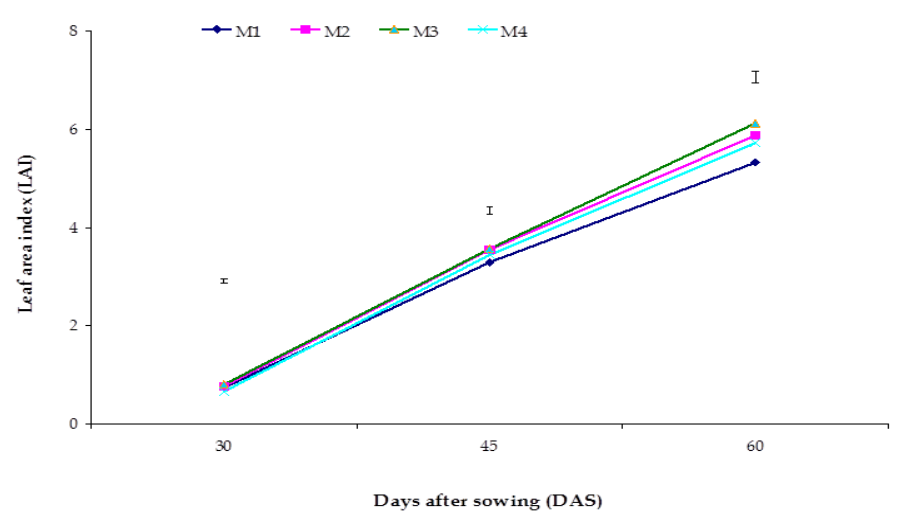

Figure 6. Effect of mulching on Leaf Area Index (LAI) at different DAS of wheat $\left(M_{1}=\right.$ control, $M_{2}=$ mulching with water hyacinth, $M_{3}=$ mulching with rice straw, $M_{4}=$ two irrigations at $C R I$ and flowering stage).

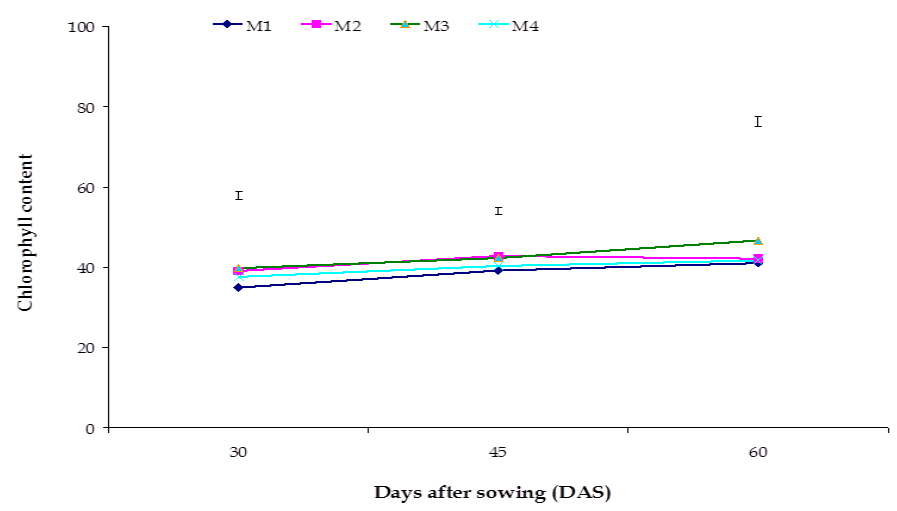

Figure 8. Effect of mulching on chlorophyll content at different DAS of wheat $\left(M_{1}=\right.$ control, $M_{2}=$ mulching with water hyacinth, $M_{3}=$ mulching with rice straw, $M_{4}=$ two irrigations at $C R I$ and flowering stage). 


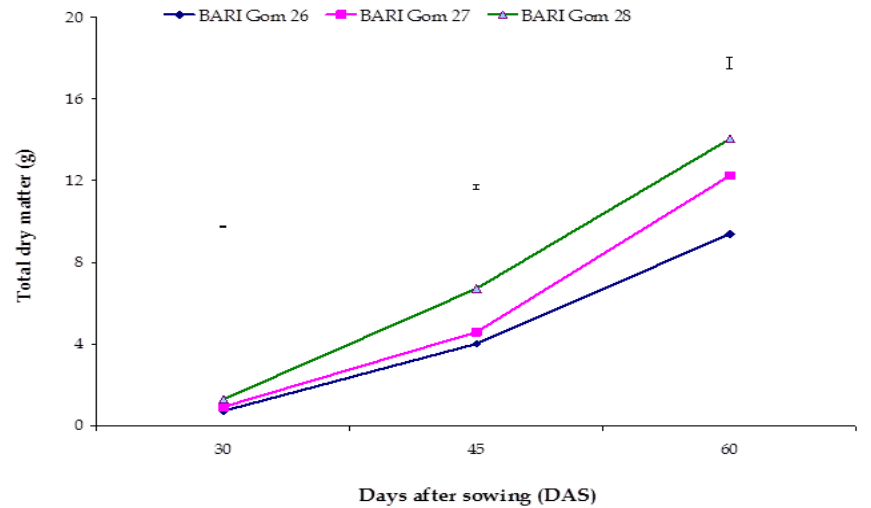

Figure 9. Effect of variety on total dry matter at different DAS of wheat.

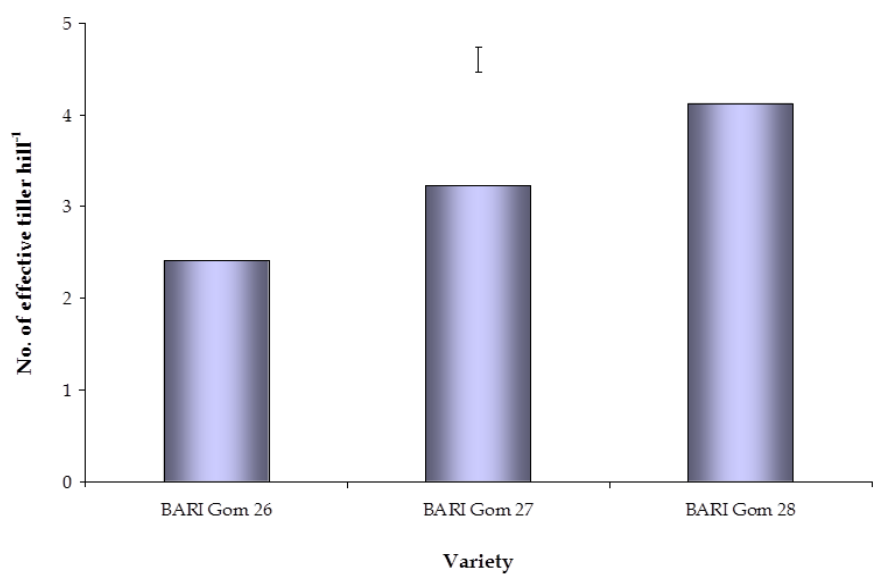

Figure 11. Effect of variety on number of effective tillers hill ${ }^{-1}$ of wheat.

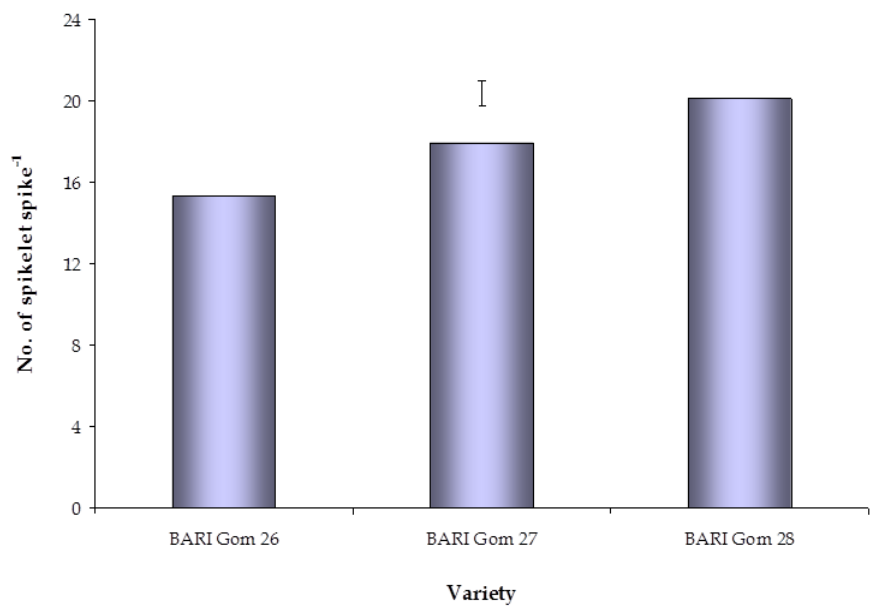

Figure 13. Effect of variety on number of total spikelets spike ${ }^{-1}$ of wheat.

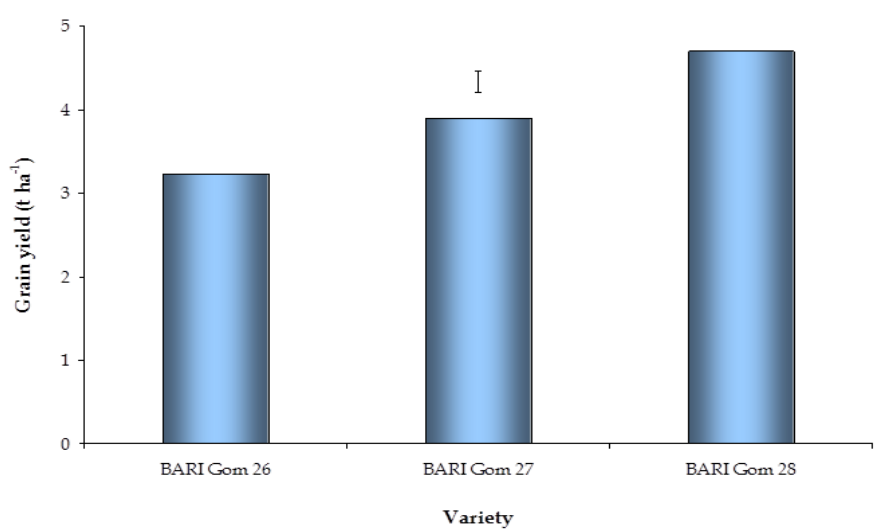

Figure 15. Effect of variety on grain yield of wheat.



Figure 10. Effect of mulching on total dry matter at different DAS of wheat $\left(M_{1}=\right.$ control, $M_{2}=$ mulching with water hyacinth, $M_{3}=$ mulching with rice straw, $M_{4}=$ two irrigations at $C R I$ and flowering stage).

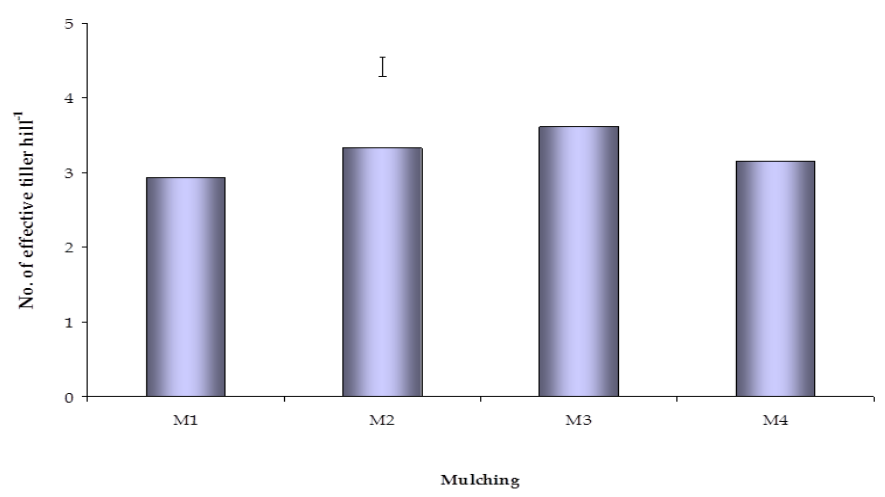

Figure 12. Effect of mulching on number of effective tillers hill ${ }^{-1}$ of wheat $\left(M_{1}=\right.$ control, $M_{2}=$ mulching with water hyacinth, $M_{3}=$ mulching with rice straw, $M_{4}=$ two irrigations at CRI and flowering stage).



Figure 14. Effect of mulching on number of total spikelets spike $e^{-1}$ of wheat $\left(M_{1}=\right.$ control, $M_{2}=$ mulching with water hyacinth, $M_{3}=$ mulching with rice straw, $M_{4}=$ two irrigations at CRI and flowering stage).

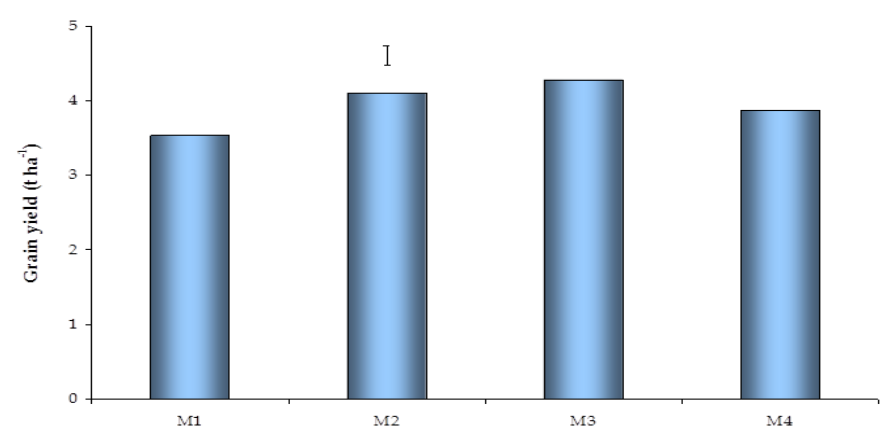

Mulching

Figure 16. Effect of mulching on grain yield of wheat $\left(M_{1}=\right.$ control, $M_{2}=$ mulching with water hyacinth, $M_{3}=$ mulching with rice straw, $M_{4}=$ two irrigations at CRI and flowering stage). 


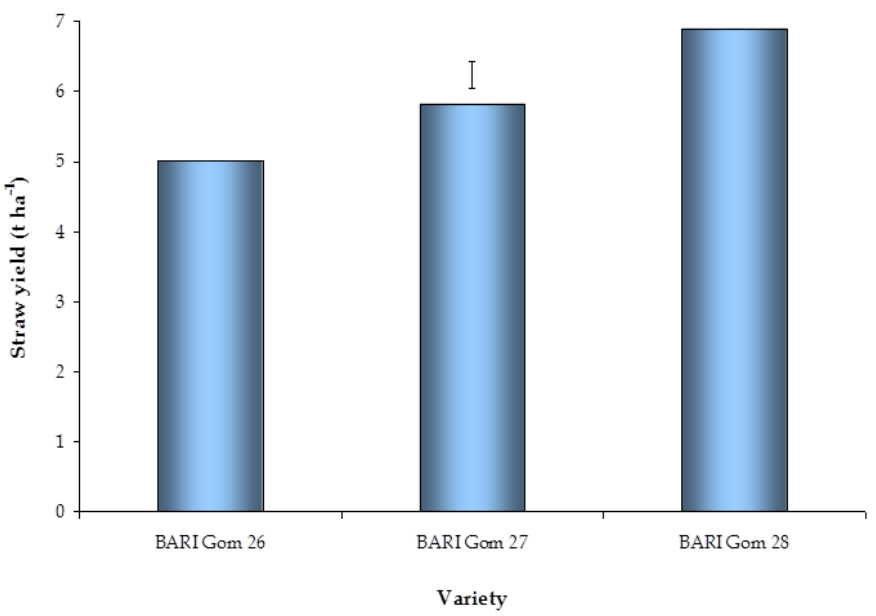

Figure 17. Effect of variety on straw yield of wheat.

Conclusion

Wheat varieties showed statistically significant variation on the growth, yield and yield contributing characteristics. BARI Gom28 produced highest yield and yield contributing parameters while lower value of all those parameters was recorded at BARI Gom-26. Similarly, mulching has profound effect on growth; yield and yield contributing characters and straw mulch seemed to be helpful for better yields. The interaction effect of varieties and mulching showed significant in relation to yield and yield components except plant height, spike length, 1000 seed weight and harvest index (\%). The highest values were obtained BARI Gom-28 with rice straw mulch. Therefore, in order to obtain higher grain yield, farmers may be advised to grow BARI Gom28 with rice straw mulch. Therefore, it may be concluded that mulching with rice straw treatment can be used successfully in an integrated way for the successful cultivation of wheat.

\section{ACKNOWLEDGEMENT}

The authors desire to acknowledge Ministry of Science and Technology (MOST), Government of the People's Republic of Bangladesh for their financial support to accomplish this research work.

Open Access: This is open access article distributed under the terms of the Creative Commons Attribution License, which permits unrestricted use, distribution, and reproduction in any medium, provided the original author(s) and the source are credited.

\section{REFERENCES}

BBS (2015). Statistical Year Book of Bangladesh. Bangladesh Bureau of Statistics (BBS) Statics and Informatics Division, Ministry of Planning, Government of the People's Republic of Bangladesh, pp. 144.

Braun, H.J., Atlin, G. and Payne, T. (2010). Multi-location testing as a tool to identify plant response to global climate change. In: Reynolds, M.P. (ed.) Climate change and crop production, CABI, London, UK. pp. 27-36.

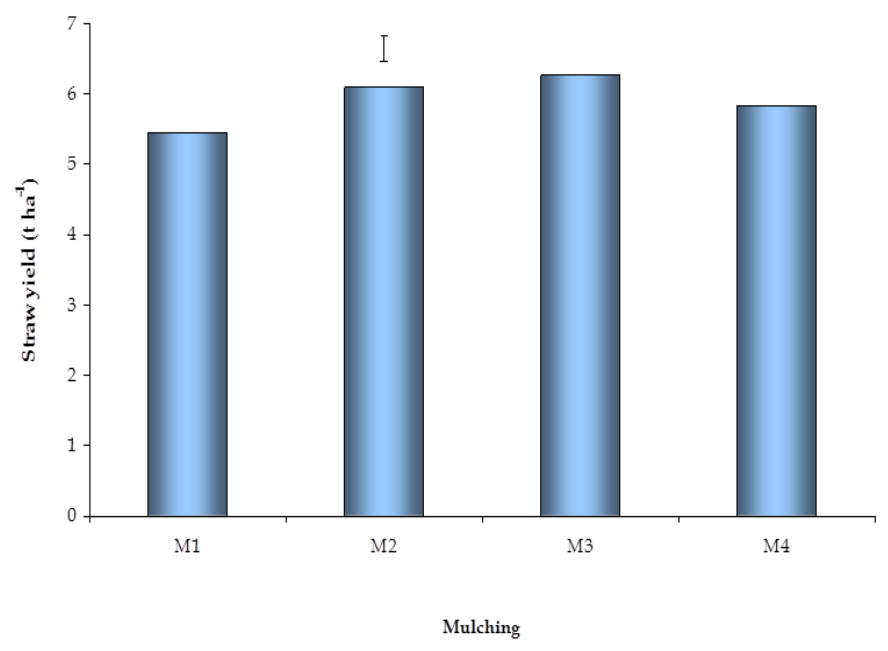

Figure 18. Effect of mulching on straw yield of wheat $\left(M_{1}=\right.$ control, $M_{2}=$ mulching with water hyacinth, $M_{3}=$ mulching with rice straw, $M_{4}=$ two irrigations at CRI and flowering stage).

Chen, L.X., Xia, S.F. and Xu, S.L. (1996). Effect of straw mulching under wheat- maize rotation system on soil fertility and crop yields. Soils, 28(3): 156-159.

Chen, Y., Liu, T., Tian, X. , Wang, X., Li ,M., Wang, S. and Wang, Z. (2015). Effects of plastic film combined with straw mulch on grain yield and water use efficiency of winter wheat in Loess Plateau. Field Crops Research, 172: 53-58.

De, R., Rao, D.V.S.B., Rao, Y.Y., Rao, L.G.G. and Ikramuls, M. (1983).Modification of irrigation requirement of wheat through mulching and foliar application of transpiration suppressants. Irrigation Science, 4(3): 215-223.

FAO (2016). Production Yearbook. Food and Agriculture Organization of the United Nations, Rome, Italy, pp.91-94.

Gomez, K.A. and Gomez A.A. (1984). Statistical Procedures for Agricultural Research.2nd Edn. John Wiley and Sons. New York pp. 680.

Hari, R., Vikas, D., Krishan, K.V. and Harinderjit, K. (2013). Grain yield and water use efficiency of wheat (Triticum aestivum L.) in relation to irrigation levels and rice straw mulching in North West India. Agricultural Water Management, 128: 92101.

Marbet, R., Moussadek, R., Fadlaoui, A. and Ranst, E. (2012). Conservation agriculture in dry areas of Morocco. Field Crops Research, 132: 84-94.

Misra, O.R.(1996). Influence of mulching and antitranspirats on water consumption yield and yield contributing characters of different rain fed wheat varieties. Crop Research (Hisar), 11(1): 1-8.

Rahman, M.A., Chikushi, J., Saifizzaman, M., Lauren, J.G. (2005). Rice straw mulch and nitrogen response of no-till wheat following rice in Bangladesh. Field Crops Research, 91(1):7181.

Sachan, S.S. (1976). Effect of mulching and fertilization on growth and yield on growth and yield of wheat. Indian Journal of Agronomy, 21(4): 484-486.

Sharma, N.K., Singh, P.N., Tyagi, P.C. and Mohan, S.C. (1998). Effect of leucana mulch on soil water use and wheat yield. 
Agricultural Water Management, 35(3): 191-200.

Stagnari, F. Qian, Y. and Cao, C. (2014). Effects of straw mulch on growth and yield of durum wheat during transition to Conservation Agriculture in Mediterranean environment. Field Crops Research, 167:51-63.

Upadhyay, V.B. and Tiwari, J.P. (1996). Influence of nitrogen, seed rate and mulch on wheat varieties under late sown conditions. Indian Journal of Agronomy, 41(4): 562-565.
Wang, P.G. and Wang, P. (1998). Effect of sowing in furrows and covering with plastic film on overwintering and yield of winter wheat. Journal of Jilin Agricultural University, 20(3): 21-24.

Zamir, M.S.I., Javeed, H.M.R., Ahmed, W., Ahmed, A.U.H, Sarwar, N., Shehzad, M., Sarwar, M.A. and lqbal, S. (2013). Effect of tillage and organic mulches on growth, yield and quality of autumn planted maize (Zea mays L.) and soil physical properties. Cercetâri Agronomice în Moldova, XLVI (2): 154. 